\title{
Children's Right to Participation in Denmark: What Is the Difference between Hearing, Co-Determination and Self-Determination?
}

\author{
Hanne Hartoft
}

The view of children changes continuously in our society. This is reflected in the fact that children are referred to as citizens with individual rights - or in terms that children are subjects and actors rather than objects. ${ }^{1}$ This includes that children's integrity and autonomy are respected. Denmark has ratified both The Convention on the Rights of the Child (CRC) and the associated protocols, and has accepted The Children's Rights Committee as an appeal board. ${ }^{2}$ However, principles from the CRC, for instance, children's rights to be heard is not incorporated into the Danish Constitution. ${ }^{3}$ The CRC is not even incorporated as a law, but by norm-harmony. This will be developed further below, but raises the question whether Denmark takes children's rights seriously and makes it interesting to analyse how children's rights to be heard and participate is actually protected and realised in Danish legislation.

Seeing children as rights-holders is supported by article 12 of the CRC, which obliges the State to 'assure to the child who is capable of forming his or her own views the right to express those views freely in all matters affecting the child'

1 Kirsten Ketcher, 'Børns menneskerettigheder: Om FN's børnekonvention i dansk ret' in Ketcher and others (eds), Nye retlige design: Dansk ret under konkurrence (Jurist- og Økonomforbundets Forlag 2003) 8. See also Caroline Adolphsen, Mindreåriges retsstilling i relation til behandling (Jurist- og Økonomforbundets Forlag 2013) 37; Hanne Hartoft, Magtanvendelse over for anbragte børn og unge (Jurist- og Økonomforbundets Forlag 2016) 94; Idamarie LethSvendsen, "Der er faresignaler her ..." Om ret og heuristik i det almindelige kommunale tilsyn med børn og unge (Roskilde Universitet 2015) 20.

2 The Government made a reservation about not being obliged to follow the decisions from the Committee on the Rights of the Child.

3 Caroline Adolphsen, 'Constitutional Rights for Danish Children' in Trude Haugli and others (eds), Children's Constitutional Rights in the Nordic Countries (Brill 2019). The Constitutional Act of Denmark of 5 June 1953 no. 169, (Grundloven), is available in an official translation, at $<$ https://www.thedanishparliament.dk/en/publications> accessed 18 January 2019.

(C) HANNE HARTOFT, 2020 | DOI:10.1163/9789004382817_016

This is an open access chapter distributed under the terms of the CC-BY-NC 4.0 Licensege Hartoft - 9789004382817 
and 'the opportunity to be heard in any judicial and administrative proceedings'. The wording of article 12 makes it visible that a modern view of children is closely linked to the understanding of 'hearing'. ${ }^{4}$ Even if the word participation is not mentioned in CRC article 12, it is often used in connection to this provision. ${ }^{5}$ In many recent Danish law reforms concerning children and adolescents, the legislator has emphasised the importance of involving the child in his or her own case in accordance with the principle of article $12 .{ }^{6}$ This is, for instance, seen in family, social and school law, and have also been an issue in health law. The development in the terminology from hearing to participation shows a tendency to more influence. However, several Danish reports show that many children have the feeling that they are not involved in their cases, for instance, when their parents' divorce or when they are in the hospital. ${ }^{7}$ This could indicate that even if the legislator emphasise the importance of involving children, this is not always realised in practice. The question is why? Is the law not clear? Do the case workers know the law? Or is it maybe because children and adolescents have wrong expectations of their rights of influence? Answering these questions require both a legal dogmatic analysis and a legal sociological approach. ${ }^{8}$ My approach is the legal dogmatic method. I will focus on the substance in the legislation but refer to a few sociological studies.

In CRC article 12 it is said that the views of the child have to be given 'due weight in accordance with the age and maturity of the child'. This is also stated

4 Hanne Hartoft, 'Et retssikkerhedsperspektiv på barnets inddragelse' in Carsten MunkHansen and Trine Schultz (eds), Retssikkerhed $i$ konkurrence med andre hensyn (Jurist- og økonomforbundets forlag 2012) 129-150.

5 For instance, UN Committee on the Rights of the Child, General Comment No. 12: The Right to be Heard (1 July 2009) CRC/C/GC/12.

6 See amendments to the Social Services Act of 24 of June 2005 no 573 (Lov om social service) now in Consolidation act of 30 August 2018 no 1114 with amendments; The placement reform of 22 December 2004 no 1442 (Anbringelsesreformen); The children's reform of 11 June 2010 no 628 (Barnets reform); The law-package about protection children against abuse and neglect of 21 May 2013 no 496 (Overgrebspakken). See also the Act on Adult Responsibility to Children in out of home placement of 8 June 2016 no 619 with amendments, now in Consolidation act of 2 may 2017 with amendments (Voksenansvarsloven); Act on Parental Responsibility of 6 June 2007 no 499 (Forceldreansvarsloven); Act of the Family-law-house of 27 December 2018 no 1702 (Lov om Familieretshuset).

7 See Birgitte Schjær Jensen, Inddragelse af udsatte børn og unge $i$ social arbejde: reel inddragelse eller symbolsk retorik? (Aalborg Universitetsforlag 2014); professional reports: Anbragte børn og unges trivsel (SFI The Danish National Centre for Social Research 2016) and Ret til inddragelse (Børns Vilkår og TrygFonden 2017). See also Anne Dorthe Hestbæk, "The Rights of Children Placed in Out-of-Home Care' in Asgeir Falch-Eriksen and Elisabeth Backe-Hansen (eds), Human Rights in child Protection (Palgrave Macmillan 2018) 129-143.

8 Leth Svendsen (note 1). 
in several Danish laws. However, at the same time, the legislation also contains many specific age limits that govern children's rights. It is not possible to find a mutual logic. ${ }^{9}$ Thus, what age and maturity can justify depends on the concrete situation, and this assessment can be difficult. Traditionally, a legal distinction is made between three different levels of participation: hearing, co-determination and self-determination. Even if these distinctions seem quite clear, it has been problematized that Danish legislation concerning children rights to participation is difficult to realise, among other things, because the rules of participation do not relate to the fact that children are subject to parental responsibility. ${ }^{10}$ This makes it is interesting to clarify what the term 'participation' actually means nowadays in Danish legislation. This leads to the research question guiding this chapter: what is the difference between selfdetermination, co-determination and hearing in Danish legislation concerning children and adolescents.

The statement is delimited to children and adolescents under 18 (in this chapter often referred to as children). Focus is on family-, social-, and health law, as this legislation cover most of the cases in which children and adolescents are involved and has an individual perspective on the child and his or her family. Additionally, the Constitution and the regulation of public schools is treated, as this regulation has a group perspective on participation.

The purpose of this chapter is to give an impression of how children's right to participation is expressed in Danish legislation. The overall idea is to use children and adolescent's everyday life as the starting point for the analysis and include both a group and an individual perspective. Other topics - for example, criminal proceedings or refugee law - are left out for space reasons, even if these subjects would bring other angles of participation forward.

In the following (section 2), the legal problems related to the Danish methods of implementing CRC is addressed. The next part (section 3) clarify that the principles of custody mean that self-determination is not the starting point for children's legal status. In section 4, there is a discussion concerning the voting age, as this is critical for the whole group of children and adolescents and their access to influence in the society. This is followed by examples of access to be heard at the group level in the school, kindergarten and leisure associations. The next parts (sections $5^{-7}$ ) focus on participation in individual case-work within family, social and health law, as the regulation is based on different rationales. In the end (section 5), conclusions are made.

\footnotetext{
$9 \quad$ Inger Dübeck, Personers rettigheder: Om individets fysiske og psykiske integritet, selvbestemmelsesret og identitet (Jurist- og Økonomforbundets Forlag 1997) 93. 
The purpose of this introduction is briefly to present the ongoing Danish discussion on incorporation of CRC. The question is whether incorporation by law instead of by norm-harmony will strengthen children's rights - including the rights to participation - and what disadvantages will follow.

In 1991, Denmark joined the Convention on the Rights of the Child. ${ }^{11}$ This ratification means that Denmark, due to public international law, is obliged to comply with the convention. ${ }^{12}$ The ratification of $\mathrm{CRC}$ had a broad political acceptance, as seems to exist today. However, the convention is not incorporated into Danish legislation by law. This means that the convention is not a part of Danish national legislation. ${ }^{13}$ However, the convention is incorporated by norm-harmony, because the Parliament assumed that Danish law was already in conformity with CRC. ${ }^{14}$ Since norm-harmony is recognised as an incorporation method for fulfilling international obligations, the CRC is a legal source. This source contribute to the interpretation of Danish law, and the Danish courts relates to whether the convention is violated. ${ }^{15}$ This is also seen in referendums from the Ombudsman - parties may invoke rights under CRC, and authorities must follow the CRC. ${ }^{16}$ If some regulation in the Danish legislation occur to be in contrast to the convention, these conflicts usually is solved by using the principles for interpretation international legal sources. ${ }^{17}$ However, the fact that CRC is not incorporated as a law has the consequence that if a Danish law is clearly contrary to CRC, this law will not be set aside. ${ }^{18}$

11 Proposal for parliamentary resolution 31 January 1991 no 22, followed by order of 16 January 1992 no 6 of the UN Convention of 20 November 1989 about the Rights of the Child (Bekendtgørelse af FN-konvention af 2o. november 1989 om Barnets Rettigheder). Denmark made a reservation against art 40, section 2 (b).

12 Anne Mørk Pedersen, Børns processuelle rettigheder i tvangsanbringelsessager (Jurist-og Økonomforbundets forlag 2019) 58-66.

13 Pedersen (n 12); Ministry of Justice report no 1407/2001 betcenkning om inkorporering af menneskerettighedskonventioner i dansk ret (report on incorporation of human rights convention in Danish legislation) and report no 1546 /2014 betcenkning om inkorporering m.v inden for menneskeretsområdet (incorporation etc at the area of human rights).

14 See the Proposal (n 11 ) section C.

15 Pedersen (n 12) 62.

16 For instance, statement of 10 April 2014, dok no 13/05229-11/CLA, Planlagte besparelser på anbringelsesområdet $i$ Guldborgsund Kommune (Planned savings in the area of children's out of home placement in the Municipality of Guldborgsund).

17 Jens Elo Rytter, Individets grundlaggende rettigheder (Karnov Group 2019) 62-64.

18 Rytter (n 17). 
Another problem is that CRC article 12, requires States to ensure that a child is involved in all decisions in their lives. The State's responsibility also applies to all other authorities, for example, regions, municipalities, courts, police, etc. Thus, the Danish Ombudsman has become aware of a legal problem in relation to some private schools (De frie grundskoler). ${ }^{19}$ They do not always hear the pupils before they are expelled. As a result, he recommended that the government take initiative to change the law concerning these schools to secure that the principle of article 12 is followed also in the private schools when they manage individual cases. For the time being, the government has not followed the advice. Thus, there is some situations where the way of implementation raises legal problems. The issue of making CRC national law has been addressed several times at official level. ${ }^{20}$

\section{Children as Subjects of Protection-Parental Custody}

As already said in chapter 7 , the Danish Constitution applies to children and adolescents, but they were not in focus when the Constitution was written. However, regulation of children's rights has a long history in Danish legislation. ${ }^{21}$ Today, children's legal position is a result of different and often conflicting considerations. The legislation tries to balance the interests between society-at-large, parents and the child. The aim is to secure children are protected from abuse, neglect and maltreatment. In addition, the regulation intends to counteract crime. Therefore, it is essential to mention the starting point - the fundamental principle in Danish law that children are subject to parental custody. This implies that children have limited legal capacity. While the starting point for adults is self-determination, it is clear that the starting point for children differs from that. In the following, this will be examined in more detail.

Custody contain two elements, the duty to take care of the child and the right to make decisions for the child. In the Act of Parental Responsibility, it is stated that parents 'have the right to make decisions in all private subjects

19 News from the Danish Ombudsmann of 28 december 2016 Lovgivning bør overvejes for at sikre, at privatskoleelever bliver hørt (Legislation should be considered to ensure that private school students are heard).

20 Pedersen (n 12).

21 Trine Shultz and others, Socialret, børn og unge (Jurist- og økonomforbundets forlag 2017) 34ff; Anette Faye Jacobsen, Stat og Civilsamfund i nye relationer: FN's børnekonventions historie i Danmark (2015) 5(10) Tidsskrift for historie. 
concerning the child'.22 This closely is related to the duty of the custody-holder to give the child a safe childhood, and to the principle of the best interests of the child, as must be followed. ${ }^{23}$ Another starting point is that parents are free to educate their children in the way the feel are best. This means that they take all vital decisions for the child for instance name, residence, school, spare-time activities, health-care, ${ }^{24}$ and so on. The parents also decide the house rules in the home and the everyday education, what to eat, and how to dress. However, at the same time, it is stated in the Parental Responsibility Act that in all decision-making, the child's own views must be taken into account according to age and maturity. ${ }^{25}$ This seems to apply to CRC. The wording of CRC article 12, is 'to ensure that a child is involved in all decisions in their own lives'. This is to be aware of the child's perspective, but more than that. ${ }^{26}$ Awareness is not enough, as the child's point of view has also to be taken into account. Even if the word participation is not incorporated in article 12, it has been the term used most often to describe what article 12 concerns. Nevertheless, participation is a broad term with no clear meaning. It is necessary to clarify the terms. Hearing is the right to be consulted without a right to decision-making. The right of co-determination is decision-making together with others (typically the custody-holder), or, in other words, having influence at the decision. Self-determination is the right to make decisions on your own. In this position, citizens have legal capacity to give consent and to choose or reject an attorney or another representative and to sue and be sued.

In a Danish report the child's perspective is formulated (in my translation) as 'the perspective that derives from and is formed through the child's overall life situation and life story. It is the whole child's life as the child experiences it. Specifically, it is about how the world looks from the child's point of view and what the child knows, sees, hears, experiences and feels in certain situations. This perspective changes as the child develops and is influenced by the changes in the child's environment.' ${ }^{27}$ In my opinion, it is more precise to talk about the child's own perspective. This, of course, is about how the child's looks at the

\footnotetext{
22 Act of Parental Responsibility section 2.

23 Act of Parental Responsibility section 4, and Caroline Adolphsen, 'Children's Right to Family Life in Denmark' in Trude Haugli and others (eds), Children's Constitutional Rights in the Nordic Countries (Brill 2019).

24 In health-care issues the parents decide up to the child is 15 . See section 7.

25 The Act of Parental Responsibility section 5.

26 Due to UN Committee on the Rights of the Child, General Comment No. 20 in the rights of the child during adolescence (6 December 2012) CRC/C/GC/20, section 23-25.

27 Rep no 1475/2006, Betænkning fra Udvalg om forældremyndighed og samvær, Barnets perspektiv (Committee on custody and contact, report on child perspective).
} 
situation. Another perspective is 'adult's perspective on children'. This is the perspective from others on what is a good life for children. Parents, caseworkers and other professionals normally represents this perspective. Previously, article 12 in Danish legislation was mostly understood as a right to hearing, thus understood as a procedural right. In this understanding, hearing is the right for the citizen (the child) who is involved in a case to get informed about the case material and to give a statement. The purpose is to be sure that the citizen is informed about what is going on, and also to give the citizen an option to correct eventually mistakes in the material. Hearing is also the citizen's opportunity to give his or her views on the case. Today, it is clearer that article 12 has both a procedural and a material perspective. This means that it is not only a formality to find out what is the child's view. The child's view on a specific matter is a part of the information in the case, as leads to the correct decision as the child's view is taken into account.

It is worth mentioning that already in 1964 children's right to express an opinion was secured in a Danish law about out-of-home placement. The child was given the right to give a personal statement. This was a right to be heard. In other legislation, children were given a right to consent. ${ }^{28}$ This was a right to self-determination. Thus, in 1991, the legal basis for considering children as rights-holders was discussed in a report that led to a new look at the relationship between, parents and children - especially in social-law cases ${ }^{29}$ However, even if the development in our society clearly shows a tendency of giving children more influence, they still are excluded from the nation-wide political level. The purpose of the next section is to get a little closer to how children and adolescents, seen as a group, are heard and get influence on their lives.

\section{Voting Rules - the Ultimate Exclusion from Influence-and Ways to Compensate}

The ultimate right to participate in a democracy is expressed by voting rights. ${ }^{30}$ Giving someone a right to vote is one way of realising hearing. The right to vote is a right to be consulted at the group level without a right to decision-making.

28 For instance, the Adoption Act, The Names Act, and the Act of the ordinary Church.

29 Rep no 1212/1990, Betcenkning fra Udvalget om de retlige rammer for indsatsen over for børn og unge (Committee on the legal framework for measures for children and adolescents).

30 For a short history review according to Danish law see Caroline Adolphsen, 'Constitutional Rights for Danish Children' (n 3). 
Children and adolescents are not allowed to vote for the Parliament, the Regional Council or the Municipal Council. Neither are they allowed to vote for the EU Parliament. The right to vote is obtained at the age of $18 .{ }^{31}$ This electoral age has been in force since $1978 .^{32}$ It is stated in the Parliamentary Election $\mathrm{Act}^{33}$ to which section 29 in the Constitution refers. The electoral age (the right to vote) coincides with the age of eligibility (the age for being elected) to the Parliament, The Regional Council and the Municipal Council. This also coincides with the age of majority. ${ }^{34}$

The voting age has been discussed several times in the Parliament and, most recently, in $2015^{-2016.35}$ The proposal was that the voting age should be reduced to 16 . This was motivated by the need to engage more young people in democracy and strengthen the participation of young people in elections. They are referred to in the report from the Electoral Commission. The debate in Parliament showed a large majority against changing the age of voting. The main argument was a reference to the age of majority and that it makes good sense that this age and the voting age is the same. In contrast to this is the fact that, in Austria, the electoral age is 18 years, although the voting age is 16 years. An argument against reducing the electoral age may be the assumption that the young voters vote more extensively than the rest of the electorate. However, experience from Austria, which reduced the voting age in 2007 from 18 to 16 , does not confirm this. ${ }^{36}$ An international survey among students in the eighth grade shows that Danish adolescents are in the first place when it comes to knowledge about democracy, politics and social relations. ${ }^{37}$ Nevertheless, students do not show the same interest in the democracy as they did years ago - as they rarely vote when there are elections. ${ }^{38}$ Lately, a number of

31 Parliamentary Election Act of 13 May 1987 with amendments in consolidation act of 8 December 2017 no 1426 with amendments (Lov om valg til Folketinget).

32 Parliamentary Election Act of 13 May 1987.

33 No $1426 / 2017$ (n 31)s 1.

34 Act on Parental Responsibility s 1.

35 On the basis of $\mathrm{B}_{13} \mathrm{O}$, FT 2015-16, proposal for parliamentary resolution no 130 from $2015^{-2016 .}$

36 Signe Rugholt Carlsen, Østrig har success med de 16 -åriges stemmer (12 September 2009), Information, referring to analyses from soRA (Institute for Social Research and Analyses), Austria.

37 Jens Bruun, Jonas Lieberkind and Heidi Bay Schunck, Udvalgte hovedresultater (DPU Aarhus Universitet 2016). See also Niels-Henrik M. Hansen and Niels Ulrik Sørensen, Unges motivation for politisk deltagelse (Center for Ungdomsforskning 2014).

38 Valgretskommissionens betænkning, Demokrati for Fremtiden (DUF- Dansk Ungdoms Fællesråd 2011). DUF is a service and interest-organisation for nationwide children's and youth organisations. The goal of the association is to educate, engage and train young people to become good democratic citizens. 
ideas was presented that would make young people more interested in politics. One was school elections. The Parliament and the Ministry of Education organise these school elections. By these elections, the students can vote for the political parties that run for the real parliamentary elections. It is a course of education aimed at students in the seventh, eighth and ninth grades. The Prime Minister announces the school election in January, and three weeks later, the students have the opportunity to vote. During the course, students should prepare campaigns, select brand cases and meet youth politicians. The school elections have been organised since 2015 - every second year. According to the evaluation, students' political self-esteem is going up, which, in the long term, will lead to more active and competent democratic citizens. ${ }^{39}$ Even if this election is symbolic, it is a kind of consultation, as the politicians are interested in knowing what the next generation of voters think.

Another approach is seen on the local political level. Approximately two-thirds of the municipalities have a Youth Council. ${ }^{40}$ However, there are differences in organisation and focus. In a big city as Århus, the Youth City Council conduct seven city council meetings a year and have an annual dialogue meeting with the politicians in Aarhus' City Council. The Youth City Council is autonomous regarding which subjects and problems they discuss. The topics are extremely varied, from the desire for a better world, to healthier food in schools, and to the establishment of a skating lane. The Youth City Council have the right to put forward four suggestions a year, which the Aarhus City Council is obligated to discuss.

After having looked into children's and adolescents' rights to be heard about questions at the national and local political level in society follows an analysis of their access to influence in their near environment. Activities

According to the regulation of public schools, the purpose of the school is together with the parents - to manage and prepare students to live in a society

39 Jonas Hedegaard Hansen, Skolevalg 2017: Undersøgelse af elevernes oplevelse med og udbytte af Skolevalg (Centre for voting and parties 2017) Working Paper Series $19 \mathrm{ff}$.

40 This is an estimate made by Netværket af Ungdomsråd NAU (NAU is a umbrellaorganisation for youth counsels). See $<$ http://www.nau.dk/ungdomsraad/> accessed 18 January 2019. Denmark is divided into 98 municipalities (and Greenland and The Faroe Islands), and approximately 65 have a youth council. 
with freedom and democracy as well as to develop and strengthen the students' democratic formation and their knowledge and respect for fundamental freedoms and human rights, including gender equality ${ }^{41}$ The local council in each municipality has the responsibility for the overall framework for the school's operation, but all schools also have a board, where the master of the school, teachers, practical staff, parents and students are represented. ${ }^{42}$ The students are parties in the board at the same level as all others. The school board does not go into individual cases, but draws up general principles and budgets and may be involved when hiring new staff. It has been criticised that the influence the students have is not real and the concept of 'pseudo-influence' has been used. The criticism is that the children are represented only in organs where they have no real power and where there is no real dialogue. ${ }^{43}$ However, the crucial aspect is that the students have the right to vote on equal terms with the other members - they are heard. But this criticism is some way central, as it precisely reflects the challenge of the right of hearing (consultation) - namely that it is not a right to decide.

According to the Public Schools Act, ${ }^{44}$ all pupils at schools with classes from level 5 or higher have the right to form Student Councils, and if they do not establish a council on their own initiative, the school management must encourage the students to do it. ${ }^{45}$ Through co-operation with the head of the school, the teachers and other staff groups, the Students Council ensures the students' interests at the school. All pupils can vote and can be elected. It is up to the Student Council to relate to what topics they want to raise. The school provides a meeting room and sometimes a small amount of funding. In the recent years, studies show that children and adolescents are increasingly stressed. ${ }^{46}$ Thus, it seems crucial to involve students in discussions about requirements and

41 Adolphsen, 'Constitutional Rights for Danish Children' ( $\mathrm{n}$ 3), for more information about education-duty. Most pupils go to public schools ( $77 \%)$. Others go to private schools, but these have to apply with the learning targets in the public school. For details see statistics from Ministry of Education (elevtal i grundskolen) <https://uvm.dk/statistik/grundskolen/elever/elevtal-i-grundskolen> accessed 18 January 2018.

42 Primary Education Act s 2 ss 2, and s 42-44.

43 Andreas Brøns Riise, 'Elever mister indflydelse' Folkekeskolen.dk (Interview with Pernille Hviid 1 February 2011) <https://www.folkeskolen.dk/66345/elever-mister-indflydelse> (accessed 22 June 2018).

44 Public Schools Act section 46.

45 See also Ministerial order 23 June 2014 no 695 about student councils (elevråd i folkeskolen).

46 Professional rep regarding stress in high school (Stress i gymnasiet, sammenfatning af resultater og anbefalinger) (DPU Aahus Universitet 2017). See also two professional rep regarding children and adolescents in Denmark Mai Heide Ottosen and others, Børn og 
expectations for school and education, not merely from a rights perspective, but also from a broader welfare perspective.

To be heard is also an issue for very young children. CRC article 12 does not entail any age limit, and the General Comment does advise the nations against creation of age limits in national law, as the right to be heard, is a right for everyone. ${ }^{47}$ In Denmark, a Children's Council (the Mini Panel) has been established. It currently consists of around 1,00o kindergarten children between four and seven. The children answer a spoken questionnaire via the computer. A study concerning the children's involvement in the day-to-day activities in the kindergarten show that most children have the feeling that the adults are listening to what they have to say. Nonetheless, more than $50 \%$ of the children claim that all rules are set by the adults. Daily routines such as lunch, activities outside of the house, and buying new toys are not activities in which the children have the feeling that their point of view counts. At that time of this report, too few children participated to make the investigation statistically valid. However, it shows that participation is a theme that seems to be discussed by professionals at many levels.

It is also relevant to comment on children's access to influence at the structural organisation of their leisure activities. The right to form associations is protected by the Constitution, ${ }^{48}$ and Denmark has a widespread union culture. It is not complicated to establish an association, and most leisure activities are organised through private associations. By being a member of a leisure association children and adolescents (and their parents) encounter different democratic processes and have access to influence. However, studies have shown that children normally do not participate in leisure-activities because of the democratic process but rather because the association offers something interesting. ${ }^{49}$

In relation to hear children and adolescents at the group level, it is difficult to say anything precise about what difference CRC and especially article 12 has made. An important effect is that CRC has pushed an ongoing tendency to see children and adolescents as citizens and consequently take their perspectives more seriously. According to Danish tradition, it is not surprising that the ratification of CRC has not been reflected in the Constitution. Making CRC a

unge i Danmark: Velfcerd og trivsel (SFI The Danish National Centre for Social Research 2014 and 2018).

47 UN Committee on the Rights of the Child, General Comment No. 12 (n 5) para 21.

48 Constitution, section 78.

49 Bjarne Ibsen and Klaus Levinsen, Unge foreninger og demokrati (Syddansk Universitet 2016) 98. 
national law would strength children's rights, but has not been a political option. The critical point is the sectorial level - and among this the regulation of voting age. It would obviously strengthen children's access to influence if the voting age was lowered. During youth councils, the group of children and adolescents are given a formal platform supporting that they are heard at the local political level. Also, the school legislation supports that students are heard. However, it is quite invisible which tracks this puts into their everyday life.

Other perspectives of being heard is seen at the individual level. In this context, the right to be heard often becomes part of the proceedings when authorities make decisions. Especially in cases regarding custody, residence and contact, the child's right to be heard is perhaps sometimes overruled. The following text comments on this issue. Why Do Parents Not Listen?

The simple answer to the headline question of why parents do not always listen is that in some divorce cases the level of conflicts is that high that all reason disappears. In general, it is problematized that children are very much affected by divorce. ${ }^{50}$ In Denmark, this is a common problem, as the parents of about every third child are separated or divorced. In respect of the parents' rights to raise their children, the child is not heard if the parents reach an agreement about parental custody, residence and contact. This can be problematic. This is shown in a study made by The National Council for Children (Børnerådet) among children in the ninth grade. ${ }^{51}$ Almost two-thirds of the children whose parents are divorced expressed that they miss the parent or siblings they do not live with, and many are dissatisfied with the extend of contact to the parent they do not live with. Contrary, a majority of the children who have been involved in the decision about which parent they should live with are satisfied with the decided arrangement. This shows the importance of involving children. This indicates that the legal regulation should ensure that the right to be heard is exercised personally by the child and not through the parents. Also, these results, in my opinion, indicates that the regulation should secure children something more than just being heard. Parental custody is an old term based on a rationale about the child's need for protection. New family patterns have emerged, and the adults have found new partners with the expectation

\footnotetext{
50 Professional rep, Familieformer og skilsmisse, Panelrapport no 1 (Børnerådet, 2011).

$51 \quad$ National Council for Children, Children's View 3/2016.
} 
that the children enter into new family relationships they have not chosen. It is essential that the child is heard and that the child's own view is a paramount consideration in these situations. Maybe, time has come to give children a right to co-determination, as this would secure that the child should not be enforced to do something against his or her will. The idea is that agreements depends on the child's consent. Currently, there is no political support for this. The following discussion informs about the newest legislation in this area.

From April 2019, a new legal system will be implemented..$^{52}$ This will make some fundamental changes in the Danish family-law system. The intentions are good. A family-law house will be established regionally, and there must be a children's department to ensure that children are appropriately involved in the process. In the proposal it is said (in my translation), that 'the consideration for the child must be a paramount consideration' and 'the process shall ensure a supportive involvement of the child ... recognizing the child's need to be heard'. ${ }^{3}$ This seems to set a new standard. The interesting question is, of course, how this will be met in the concrete process. The problem mentioned above will still exist. In some cases, the parents agree about custody, residence and contact and the child is not heard. However, it is recognised in the regulation that also these children may need some help and they are offered to participate in 'children groups' without any visitation. Further, it is stressed that children have a right to ask the children's department to set up a meeting with the parents, if he or she needs help to express him or herself. That is the socalled initiative right.${ }^{54}$ An important aim with this reform is to teach parents how to deal with conflicts, and focus more of the needs of the child. Another aim is to avoid enforcements. Today there are a large number of cases where the bailiff's court together with the police enforces relocation of residence or contact-orders. This is problematic, as it can and be traumatic for a child. ${ }^{55}$

In the preparatory works it is stressed that the establishment of the children's department is strengthening the child's voice and the child's participation in the process. This is realised through offering a contact person, information of the right to bring a companion (a person who support without being a legal representative), and ensuring that the child is informed about how the children's department can help. ${ }^{56}$

52 Act no 1702/2018, The Family-house Act.

53 Proposal of 2018-19 no 9o on The Family-house Act.

54 Parental Act s 35, and The Family-house Act s 15 ss 4.

55 (n 61) general comments section 3.3.1.2.

$56 \quad(\mathrm{n} 61)$ general comments section 2. 
In divorce and separation cases, there is a significant but seemingly insoluble problem: it is politically a very clear starting point that a child is entitled to both parents. Politicians in all contexts express this and, no doubt, this a true starting point. However, it seems that this principle has been managed so significantly that it also becomes a duty for the child to have relations with both parents. Only in very rare cases, contact can be denied, for instance, in situations with violence or abuse or a high level of conflict between the parents. ${ }^{57}$ Otherwise, children are not allowed to reject contact even for only a shorter period, where they might need a break to get used to the new situation. It may be critical when the child's own perspective is overruled by the adults' perspective of a good childhood. This shows the 'down-side' of hearing - it is problematic when a child is heard, but does not have any influence. When these cases are treated in the administrative system or is brought to court, it is the absolutely the main rule that the child is heard. In the hearing, it is central for the case-worker or the judge to tell the child that he or she is not going to take the decision in the matter whatever it concerns custody, residence or contact. That job is for 'the adult' (case-worker or judge). Sometimes it may be a relief for the child to know this, but not always. Thus, it is a fact that contact and relocation of residence against the child's wish sometimes is affected. ${ }^{58}$ In a concrete case, a 13-year-old boy was returned to his mother even though he wanted to stay with his father, with whom he had been for holiday. In other words, the child was heard, but did not get his wishes through. Is this in accordance with his age and maturity? It is interesting to see if the new system will make real changes and listen more to the children. Another area with many concrete decisions as affect children is the social welfare system, as is discussed below.

\section{Does a Conversation Make a Difference in Social Work?}

The Social Service Act contains different rules that are intended to secure that the child's views should always be taken into account in cases concerning social care. ${ }^{59}$ In cases with some complexity, the question is if the child or family can get some intensive support. ${ }^{60}$ This depends on whether the child has

57 Ministry of Social and the Interior affairs, Administrative guidelines on contact of 2015 no 11362 point 14 (Vejledning om samvær). See also Ugeskrift for Retsvæsen (2015).465 judgment from Western High Court regarding an unusually high level of conflict as threatening the child's wellbeing.

$5^{8} \quad$ Fuldmægtigen (2016).14 (judgment from Eastern High Court).

59 The Social Service Act s 46 ss 3 and s 5 o ss 3.

6o Chapter eleven in the Social Service Act. 
a need for 'special measures'. It is not clearly defined when this criterion is fulfilled, but social case-workers have to make an investigation to clarify the situation. ${ }^{61}$ This is the Child investigation report (børnefaglig undersøgelse). This report is not only based on information from the child and the family, but also from other relevant sources, for instance, the school, health-care persons and other specialists. The child (and the custody-holder) must in this process be offered one or more conversations. Further, a conversation normally should be offered before the case-worker makes a final decision of what measures may be initiated. ${ }^{62}$ The Social Service Act contains a provision that clarifies the purpose of giving welfare support to children. In this, it is said that the child's view must always be included and must be given an appropriate weight, based on age and maturity. ${ }^{63}$ This provision was incorporated into the Social Service Act to comply with the principles from CRC article $12 .{ }^{64} \mathrm{~A}$. Mørk systematically reviews all provisions in the Social Service Act and notice that the wording in the provisions differs as both conversation (samtale), making a decision (stillingtagen) and making a statement (udtaleret) is used. ${ }^{65}$ However, Mørk conclude that all the provisions is a right to be heard, but often with the broad perspective from article 12. Hearing is a process where the child is going to have the feeling of being respected, and given the strongest possible self-determination.

As said above this norm of giving the child's view a weight due to age and maturity is difficult to describe, as it depends on the concrete situation. It opens up an assessment. What weight is given to the child's point of view if the parents agree - or if they disagree? How is the child's view weighted if his or her interests is contrary to a sibling's interests and needs? And what is the situation if the child maybe is abused and is afraid of telling what is going on? In family relationships, there are many interests to take into account. I. Leth Svendsen, who has made both a legal dogmatic and a legal sociological investigation of this legislation, argues that the provisions even if they seems clear are difficult to fulfil, as the criterion of weight due to age and maturity is vague and inaccurate. ${ }^{66}$ It can be discussed whether the wording of the law is a problem. The point is that the case-worker has a huge duty to take all

\footnotetext{
$61 \quad$ The Social Service Act s 5 o.

62 The Social Service Act s 48.

63 The Social Service Act s 46 ss 3.

64 Proposal of 16 April 1997 no 229, general comments section 2.

65 Mørk (n 12) 187-222.

66 (n 1) 175. This is confirmed by Ditte Andersen and Tea Torbenfeldt Bengtsson, "Timely care: Rhytms of bureaucracy and everyday life in cases involving youths with complex needs' (2018) Time \& Society $1-23$.
} 
considerations in account and has to be clear in the argumentation. From a legal perspective, this require good case-work to be able to clearly describe how these considerations are included in the final decision. As pinpointed in General Comments no 12, the right to be heard means that the child should have the feeling that the decision-makers are listening. This also is the intention of the Social Service law. Nevertheless, it is reported that children not always have this experience. ${ }^{67}$ Another explanation could be that the social-workers is not used talking with children. This makes it difficult to realise a good conversation. Another explanation could be that the case-workers have too little time. This is crucial. Further, a crucial problem could be that it is not always possible to find solutions that meets what the child wants. As the social service law is quite flexible, this could be a question of money.

In rare situations, the conversation can be omitted. However, the child's attitude must always be sought. ${ }^{68}$ Another point is that the child, of course, is not obliged to speak up. It is an offer not a duty. ${ }^{69}$

Adolescents over 15 have a stronger position. They have, as a starting point, to consent to a childcare-investigation and decisions of measurements. ${ }^{70}$ If a placement outside of home is to be considered voluntary, it is also necessary that adolescents over 15 give a consent. ${ }^{71}$

This is an example of co-determination as the custody-holder mostly have to consent, too. If the adolescents do not consent moving to an out-of-home placement, the case-worker cannot automatically start up a case of involuntary placement. The legal criterion for involuntary placement demands a very serious situation as maybe is not realised.

In cases concerning involuntary placement outside home (and other drastic measures), children over 12 in addition to the right to be heard in relation to the child investigation report have certain procedural rights. ${ }^{72}$ This is a right for free legal assistance, access to the case-files, and the right to express oneself at the Child and Youth Board meeting (the board that takes the decision if the local social service find it is necessary to move the child away from home without consent from the parents). Further, they may appeal to the Appeal board, and if necessary ask the Appeal board to bring the case to the courts. ${ }^{73}$

$67 \quad$ (n 7$)$ and (n 65).

68 The Social Service Act s 48 ss2.

69 Caroline Adolphsen, Barnets ret til (at blive fri for) at blive hørt (2018) Ugeskrift for Retsvæsen 83-9o.

70 The Social Service Act s 50 ss 1.

71 The Social Service Act s 52 ss 1.

72 The Social Service Act s 72.

73 The Social Service Act s168 and 169 . 
These 'party-rights' gives the child a limited right of 'self-determination,' as realisation of these rights does not depend on consent from the custodyholder. The custody holders have the same rights. Mørk argue that it is problematic that children under 12 do not have the same rights, as children has to have this help in all situations where the child and his or her parents maybe conflicts. ${ }^{74}$

As demonstrated above, the Social Service Act has several provisions designed to ensure children's right to be heard. This makes it interesting to investigate the situation if a child is involved in a case but the right to be heard is not regulated. The question is if the child is entitled to derive a right to participating from the inquisitorial system - also known as the principle of investigation (officialprincippet). This principle makes the authorities (the case-worker) responsible for the case to be sufficiently clarified. Regarding social matters, the principle is stated in the due process section of the Social Law Act. ${ }^{75}$ For other cases, it is applied as a legal doctrine, as it generally applies to public administration. In this regard, the Ombudsman already in 1992 said that a duty to obtain an opinion from an older child or adolescents follow from the principle of investigation. ${ }^{76}$ Furthermore, he stresses that although there are specific rules saying that children over 12 should be heard, this does not exclude the authorities from involving younger children - and in this connection he also explicitly refers to CRC article 12. Mørk agrees with this argumentation. This point of view has not been earlier highlighted in the children's rights literature but supports children's right to be heard whatever their age is. ${ }^{77}$ The following comment is on a different approach as is seen in the Health Act.

\section{Self-Determination - an Unusual Right for Children}

In the field of health law, children have been formally involved in decisionmaking concerning their own health with the Patients' Legal Position Act from 1998, when the right of decision-making for young patients was clarified. The approach to autonomy has led to the fact that adolescents over 15 have a right to consent or refuse treatment. ${ }^{78}$ Also, the parental custody-holder must have

\footnotetext{
74 See Mørk (n 12).

75 See section 10.

76 FOU 1992.334. Opinion from the Ombudsman in the annual report, 1992 no. 334, commented in Rikke Gottrup, Officialprincippet og sagsoplysning: mod øget borgerinddragelse? (Jurist- og Økonomforbundets forlag 2011) 186ff.

77 See Mørk (n 12).

78 See the Health Act s 17 ss 1.
} 
the same information as the adolescent as the decisions can be taken after a joint discussion. This 'process' is not clear from the wording of the provision, but the provision must be interpreted in the light of the preparatory works. ${ }^{79}$ A joint discussion is not the same as a joint agreement, and if the parent and the adolescents disagree, the patient makes the decision. In order to avoid unreasonable pressure from parents, adolescents may even oppose access to the hospital room. The age criterion was chosen to avoid health-care persons from making the difficult assessment of what age and maturity could justify. However, there are also studies showing that children feel overlooked and exposed to something they do not want. ${ }^{80}$

\section{$9 \quad$ Conclusion}

The fact that children's right to participation is not incorporated into the Constitution it is not a critical problem. The CRC is an important legal source and a driver for developing children's rights. Both private organisations, state councils and the children's office at the Ombudsman's bring children's rights to the political level and often the right to participate is in focus. The right to be heard is incorporated in much legislation, but it is a challenge to step up at the ladder of participation and realise the feeling of being involved. However, Denmark is taking children's rights seriously.

\section{References}

Adolphsen C, 'Constitutional Rights for Danish Children' in Trude Haugli and others (eds), Children's Constitutional Rights in the Nordic Countries (Brill 2019).

Adolphsen C, 'Children's Right to Family Life in Denmark' in Trude Haugli and others (eds), Children's Constitutional Rights in the Nordic Countries (Brill 2019).

Adolphsen C, Mindreåriges retsstilling i relation til behandling (Jurist- og økonomforbundets Forlag 2013).

Adolphsen C, Barnets ret til (at blive fri for) at blive hort (2018) Ugeskrift for Retsvæsen 83-90.

79 See L 15 1997-98, FT 1997-98 A, 2. saml., s. 528, the specific remarks to section 8 in the previously Act on patient's legal status. The rules are supplemented by a notice (no 509 of 13 May 2018). The guidance (No 161 of 16 September1998) is still in force, but not up to date.

8o See professional rep I'm not my illness (Jeg er ikke min sygdom) (Børnerådet 2017). 
Andersen J, Socialforvaltningsret (Jurist- og Økonomforbundets Forlag 2016).

Andersen D and Torbenfeldt Bengtsson T, 'Timely care: Rhytms of bureaucracy and everyday life in cases involving youths with complex needs' (2018) Time \& Society $1-23$.

Bruun J, Lieberkind J and Bay Schunck H, Udvalgte hovedresultater (DPU Aarhus Universitet 2016).

Dübeck I, Personers rettigheder: Om individets fysiske og psykiske integritet, selvbestemmelsesret og identitet (Jurist- og økonomforbundets Forlag 1997).

Faye Jacobsen A, Stat og Civilsamfund i nye relationer: FN's børnekonventions historie i Danmark (2015) 5(10) Tidsskrift for historie.

Gottrup R, Officialprincippet og sagsoplysning: mod øget borgerinddragelse? (2011) Jurist- og Økonomforbundets forlag.

Hansen M N and Sørensen N E, Unges motivation for politisk deltagelse (2014) Center for Ungdomsforskning 2014.

Lausten M and Jørgensen T, Anbragte børn og unges trivsel (2016) SFI.

Hansen J H, Skolevalg 2017: Undersøgelse af elevernes oplevelse med og udbytte af Skolevalg 2 (2017) Centre for Voting and parties, Paper Series.

Hartoft H, 'Et retssikkerhedsperspektiv på barnets inddragelse' in Carsten MunkHansen and Trine Schultz (eds), Retssikkerhed $i$ konkurrence med andre hensyn (Jurist- og økonomforbundets forlag 2012).

Hartoft H, Magtanvendelse over for anbragte børn og unge (Jurist- og økonomforbundets forlag 2016).

Hestbæk D, 'The Rights of Children Placed in Out-of-Home Care' in Asgeir FalchEriksen and Elisabeth Backe-Hansen (eds), Human Rights in child Protection (2018) Palgrave Macmillan, open access at <https://www.palgrave.com/de/book/ 978331994799o > accessed 22 December 2018.

Andreas Brøns Riise, 'Elever mister indflydelse' Folkeskolen.dk(1 February 2011)<https:// www.folkeskolen.dk/66345/elever-mister-indflydelse> accessed 22 June 2018.

Ibsen B and Levinsen K, Unge foreninger og demokrati (Syddansk Universitet 2016).

Justitsministeriet, betcenkning om inkorporering af menneskerettighedskonventioner $i$ dansk ret, Rep no 1407/2001. (Justitsministeriet 2001).

Justitsministeriet, betænkning om inkorporering m.v. inden for menneskeretsområdet, Rep no 1546/2014 (Justitsministeriet 2001).

Ketcher K, 'Børns menneskerettigheder: Om FN's børnekonvention i dansk ret' in Ketcher and others (eds), Nye retlige design: Dansk ret under konkurrence (Jurist- og Økonomforbundets Forlag 2003).

Leth-Svendsen I, “Der er faresignaler her ...,": om ret og heuristik i det almindelige kommunale tilsyn med børn og unge (Roskilde Universitet 2015).

Mørk A, Børns processuelle rettigheder i tvangsanbringelsessager (Jurist-og Økonomforbundets forlag 2019). 
Ottosen M H and others, Børn og unge i Danmark: Velfcerd og trivsel (SFI The Danish National Centre for Social Research 2014 and 2018).

Professional rep, Familieformer og skilsmisse, Panelrapport no. 1. (Børnerådet, 2011).

Professional rep, Stress i gymnasiet, sammenfatning af resultater og anbefalinger (DPU Aahus Universitet 2017).

Professionel rep, Jeg er ikke min sygdom (Børnerådet 2017).

Professionel rep, Ret til inddragelse (Børns Vilkår og TrygFonden 2017).

Rytter JE, Individets grundlceggende rettigheder (Karnov Group 2019).

Schultz T and others, Socialret, børn og unge (Jurist- og økonomforbundets forlag 2017).

Schjær Jensen B, Inddragelse af udsatte børn og unge i socialt arbejde: reel inddragelse eller symbolsk retorik (Aalborg Universitetsforlag 2014).

Udvalget om de retlige rammer for indsatsen over for børn og unge, Betcenkning. Rep no 1212/199o (Commitee on the legal framework for measures for children and adolescents).

Udvalget om Forældremyndighed og samvær, Barnets Perspektiv. Rep no 1475/2006, (Familiestyrelsen 2006).

Valgretskommisionen Betænkning Demokrati for fremtiden (DUF-Dansk Ungdoms Fællesråd 2011).

UN Committee on the Rights of the Child, General Comment No. 20 in the rights of the child during adolescence (6 December 2012) CRC/C/GC/2O.

UN Committee on the Rights of the Child, General Comment No. 12: The Right to be Heard (1 July 2oog) CRC/C/GC/12.

Undervisningsministeriet, Statistics (Elevtal i grundskolen) $<$ https://uvm.dk/statistik/ grundskolen/elever/elevtal-i-grundskolen> accessed 18 January 2018. 